\title{
Factors Associated with the Use of Non-Hormonal Contraceptive Methods in the Pantoloan Public Health Center Palu City
}

\author{
Nur Rosmala ${ }^{1}$, Abd. Rahman ${ }^{2}$, Dhevy Febriani ${ }^{1}$, Sendhy Krisnasari ${ }^{\star},+3$ \\ ${ }^{1}$ Biostatistic, Family Planning and Demography Department \\ ${ }^{2}$ Health Promotion Department \\ ${ }^{3}$ Public Health Faculty Tadulako University, Palu City Indonesia \\ DOI:https://doi.org/10.15520/jcmro.v2i03.134
}

Accepted 14-02-2019; Received 21-02-2019; Publish Online 18-03-2019

\author{
Reviewed By: \\ Dr V. Daniel \\ Department: \\ Reviewer/CMRO
}

\begin{abstract}
Non-hormonal contraception is an action to prevent conception or pregnancy hormones include (IUD, condoms, operating methods lady/MOW, operation method man/MOP), This method can prevent pregnancy up to $99 \%$. The purpose of this study was to determine whether the factors of family support, education, economic status, and knowledge associated with the use of non-hormonal contraception. This type of research is quantitative research design used by the cross sectional approach. The population in this study were all active family planning acceptors who visit the Tawaeli Health Center Palu subdistrict Pantoloan 2018 as many as 674 people.The sampling technique is to use a non-probability sampling technique accidental sampling, The total sample of 84 respondents. Data collection was conducted by filling out a questionnaire as a tool for an interview. Data were analyzed by univariate and bivariate, at the level of $95 \%(\mathrm{P} \leq 0.05)$. Chi square test results showed that family support, education, economic status and knowledge of respondents associated with the use of non-hormonal contraception with a p-value $\leq 0.05$.It is expected that the community can be open and willing to receive information from health workers related to family planning.
\end{abstract}

Key words: Contraception-Non Hormonal-Methods

\section{INTRODUCTION:}

The high birth rate in Indonesia is still a major problem in the population. Since 2004, the Family Planning (KB) rated running slowly, until the birth rate of 4.5 million per year and in 2010, based on census population reached 237 million. Conscious population explosion will affect the availability of food and the quality of human resources. To avoid these impacts, government strives to reduce the number of births to below 237 million per year [1] ,

Report the results of contraceptive services in Indonesia in 2015 , the data obtained planning participants with details of injectable contraceptive users 33345 participants (52.4\%), 15.162 pill participants $(22.2 \%), 9.125$ IUD participants (14.10\%), 7.400 implant participants (11.40\%),

\footnotetext{
* Corresponding author.

$\dagger$ Email: krisnasarisendhy@gmail.com
}

3.911 MOW participants (4.01\%), 3.642 condoms participants $(4.77 \%)$ and 105 MOP participants $(0.52 \%)$. In October 2013 report noted the results of a new family planning acceptors services in Indonesia as many as 96.270 participants. Details of the results of new services planning participants as follows: as many as 47.103 participants injection (50.10\%), 18.095 pill participants (19.31\%), 18.328 IUD participants (18.21\%), 11.019 implants participants (13.03\%), MOW participants 5.851 (5.91\%), 3.100 condom participants $(4.10 \%)$, and 106 MOP participants $(0.16 \%)$. [2-4]

Central Sulawesi Province in 2016 showed that the level of participation in family planning is good enough, of the number of couples of reproductive age (EFA) currently available (529.095) which is currently active planning participants (PA) amounted to 413.944 persons. From the number of active participants tool non-hormonal contraceptive methods (IUD, MOW, MOP, Condoms). Of these non-hormonal level of participation amounted to only 47.061 people of the 


\section{Comparative Study of the Effect of Topical Corticosteroid with Non-Steroidal Anti Inflammatory Agents on Post-Operative Inflammation and Corneal Astigmatism After Cataract Surgery

total PA [5],

Recapitulation of the methods of non-hormonal contraceptives and hormonal contraceptive method based on Palu City Health Department in 2016 stated that the total amount of EFA 61.229 people using non-hormonal methods: IUD 10.087, MOW 1.888, MOP 75, condoms 827, while the use of hormonal contraceptives: 5.290 implants, injectable $8.380,6.737$ pills [5], In fact, many of the difficulties experienced by women in determining the appropriate contraception for herself. Constraints that are often found arise due to lack of knowledge. Many aspects of health status, possibility of failure or unwanted pregnancy, expected number of family ranges, consent of husband or wife, cultural, environmental and family values so on. This study wants to know whether family support, education, economic status and knowledge are related to the use of non-hormonal contraception?

\section{METHODS:}

Research is quantitative research. The study design was used through a cross sectional approach. The study was conducted at the Pantoloan Health Center in Tawaeli District, Palu City, from August to September 2018. The population in this study were all active family planning physicians visiting the Pantoloan Health Center in Tawaeli District, Palu City in 2018 as many as 674 people. The sample in this study is that some $\mathrm{KB}$ acceptors are active in the Pantoloan Community Health Center Working Area which based on the calculation obtained a sample size of 84 respondents. The sampling technique is by way non probability sampling which is accidental sampling. Data collection is done by filling out the questionnaire as an interview aid. Data were analyzed by univariate and bivariate, at the level of $95 \%(\mathrm{p} \leq 0.05)$.

\section{RESULTS:}

1. Relationship Between Family Support and Non-hormonal Contraceptive Use in the Work Area of Pantoloan Health Center, Tawaeli District, Palu City

Table 1. Analysis of the Relationship Between Family Support with Non-Hormonal Contraceptive Use in the Work Area of Pantoloan Health Center, Tawaeli District, Palu City

\begin{tabular}{|c|c|c|c|c|c|c|}
\hline \multirow[t]{3}{*}{ Family support } & \multicolumn{4}{|c|}{$\begin{array}{l}\text { Non-Hormonal } \\
\text { Contraceptive Use }\end{array}$} & \multicolumn{2}{|r|}{ p-value } \\
\hline & $\begin{array}{l}\text { Do } \\
\text { use }\end{array}$ & not & Use & & & \\
\hline & & $\%$ & & $\%$ & & $\%$ \\
\hline Does not support & 45 & 72.3 & 3 & 27.7 & 48 & 100.0 \\
\hline Support & 19 & 56.2 & 17 & 43.8 & 36 & $100.0 \quad 0,002$ \\
\hline total & 58 & 57.9 & 26 & 42.1 & 84 & 100.0 \\
\hline
\end{tabular}

In table 1 shows that respondents with families that do not support more that use non-hormonal contraception that is as much as 45 respondents (72.3\%) compared with families that support non-hormonal contraceptive use as many as three respondents $(27.7 \%)$. While respondents with more family support did not use, namely 19 respondents $(56.2 \%)$ compared to those using non-hormonal contraception, namely 17 respondents $(43.8 \%)$. Based on the results of the analysis using Chi-Square conducted on family support with the use of non-hormonal contraception, a $\mathrm{p}$ value of $0.002(\mathrm{p} \leq 0,05)$ was obtained, then $\mathrm{H} 0$ in this study was rejected and Ha was accepted. This means that there is a relationship between family support and the use of non-hormonal contraception in the work area of Pantoloan Health Center. Relationship Between Education and NonHormonal Contraceptive Use in the Work Area of Pantoloan Health Center, Tawaeli District, Palu City

2. Relationship Between Education and Non-Hormonal Contraceptive Use in the Work Area of Pantoloan Health Center, Tawaeli District, Palu City

Table 2. Analysis of the Relationship Between Education with Non Hormonal Contraceptive Use in the Work Area of Pantoloan Health Center, Tawaeli District, Palu City

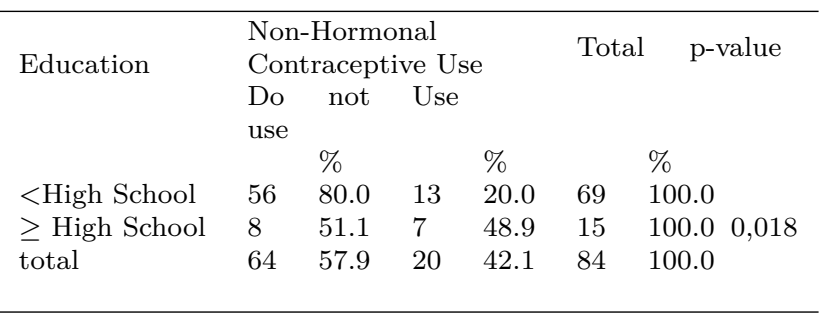

Table 2 shows that respondents with education $<$ High School more who do not use non-hormonal contraception as many as 56 respondents $(80.0 \%)$ Compared with the use of non-hormonal contraception as many as 13 respondents (20.0\%). Respondents with education $\geq$ High School more likely to use non-hormonal contraception than those who did not use that 8 respondents $(51.1 \%)$ than 7 respondents (48.9\%). Based on the analysis performed using chi square to education with the use of non-hormonal contraceptives, was obtained $\mathrm{p}$ value of 0.018 ( $\mathrm{p} \leq 0.05$ ), H0 in this study was rejected and Ha accepted. This means there is a relationship between education with a non-hormonal contraceptive use in Pantoloan Health Center.

3. Relationship Between Economic Status and NonHormonal Contraceptive Use in the Work Area of Pantoloan Health Center, Tawaeli District, Palu City

Table 3. Analysis of the Relationship Between Economic Status with Non Hormonal Contraceptive Use in the Work Area of the Pantoloan Health Center, Tawaeli District, Palu City

\begin{tabular}{llllllll}
\hline \multirow{2}{*}{ Economic Status } & \multicolumn{4}{l}{$\begin{array}{l}\text { Non-Hormonal } \\
\text { Contraceptive Use }\end{array}$} & Total & p value \\
& $\begin{array}{l}\text { Do not } \\
\text { use }\end{array}$ & & & & & & \\
Less & 50 & 80.0 & 4 & 20.0 & 54 & 100.0 & \\
Enough & 14 & 48.9 & 16 & 51.1 & 30 & 100.0 & 0,002 \\
total & 64 & 57.9 & 20 & 42.1 & 84 & 100.0 & \\
\hline
\end{tabular}


Table 3 shows that respondents with economic status more or less the use of Non Hormonal contraception, which does not use that is as much as 50 respondents ( $80.0 \%$ ) compared to those who use Non Hormonal contraception who use as many as 4 respondents ( $20.0 \%$ ). Respondents with enough more use non-hormonal contraceptives that use as many as 16 respondents $(51.1 \%)$ compared to those who did not use non-hormonal contraceptives as many as 14 respondents $(48.9 \%)$. Based on the results of the analysis using chi-square conducted on economic status with the use of non-hormonal contraception, $\mathrm{p}$ values of 0.002 ( $\mathrm{p} \leq 0,05)$ were obtained, then $\mathrm{HO}$ in this study was rejected and $\mathrm{Ha}$ be accepted. This means there is a relationship between economic status and the use of non-hormonal contraception in the work area of the Pantoloan Health Center.

4. Relationship Between Knowledge and Non Hormonal Contraceptive Use in the Work Area of Pantoloan Health Center, Tawaeli District, Palu City

Table 4. Analysis of the Relationship Between Knowledge with Non Hormonal Contraceptive Use in the Work Area of Pantoloan Health Center, Tawaeli District, Palu City

\begin{tabular}{|c|c|c|c|c|c|c|c|}
\hline \multirow[t]{3}{*}{ Knowledge } & \multicolumn{4}{|c|}{$\begin{array}{l}\text { Non-Hormonal } \\
\text { Contraceptive Use }\end{array}$} & \multicolumn{2}{|c|}{ Total } & \multirow[t]{3}{*}{$\mathrm{p}$-value } \\
\hline & $\begin{array}{l}\text { Do } \\
\text { use }\end{array}$ & not & Use & & & & \\
\hline & & $\%$ & & $\%$ & & $\%$ & \\
\hline Not good & 51 & 76.7 & 1 & 23.3 & 52 & 100.0 & \multirow{3}{*}{0,002} \\
\hline Well & 7 & 42.3 & 25 & 57.7 & 32 & 100.0 & \\
\hline total & 58 & 57.9 & 26 & 42.1 & 84 & 100.0 & \\
\hline
\end{tabular}

Table 4 shows that respondents with less good knowledge more that do not use as many as 51 respondents $(76.7 \%)$ Compared with the use of non-hormonal contraception as many as one respondent $(23.3 \%)$. Respondents with a good knowledge more that use non-hormonal contraception as many as 25 respondents (57.7\%) Compared with those not using as many as seven respondents (42.3\%). Based on the results using a chi-square analyzes were conducted on knowledge with the use of non-hormonal contraceptives, was obtained $\mathrm{p}$ value of $0.002(\mathrm{p} \leq 0.05)$, then $\mathrm{HO}$ in this study was rejected and Ha accepted. This means there is a relationship between knowledge with the use of non-hormonal contraception in the work area of Pantoloan Health Center.

\section{DISCUSSION:}

\section{Family Support Relations with Non-Hormonal Con- traceptive Use}

Family support is an important factor in helping people solve problems, family support will increase confidence and motivation to confront the problem and increase life satisfaction. In this case the family should be involved in educational programs so families can meet the needs of patients, families know when to seek help and support adherence to treatment [6] .
Approval of a family is seen as the key to decide to use non-hormonal contraception. More than $50 \%$ of all couples who undergo non-hormonal contraception in Tanzania said that the approval of the family as a factor in decisionmaking [7].

Based on the results using a chi-square analysis of the obtained results that there is a relationship between family support with the use of hormonal contraception in Pantoloan Health Center, This means that family supportvery influential in the decision to use or not and what methods will be used. In addition an important role in supporting decision-making, the role of the family in providing information is also devastating for the patient. Roles such as participating during the consultation on the health workers when the wife/husband would use contraceptives, remind your wife/husband to control the schedule.

The results are consistent with research conducted by Liando, that there is a significant relationship between the spousal support IUD contraceptive use by the results of the bivariate analysis of factors husband's support with the use of an IUD Contraception demonstrate the value of ChiSquare with $\mathrm{p}$ value of $0.005(\mathrm{P}<0.05)[8]$.

According to this study is very necessary agreement between husband and wife in the use of non-hormonal contraceptive method. The existence of an agreement between the two of contraception used by the husband/wife can lead to use of contraceptives continues over which is a business decline in fertility levels. According to the wife that her husband reason to provide support so that his wife is not fast any more children or to adjust spacing pregnancies. Because if you have lots of children difficult to meet their needs. While respondents who have the support of their husbands in use contraception between husband and wife because more wanted an ideal family ( 2 children) and when to have a lot of children [9] .

This is consistent with the theory that a wife in the decision to use or not use contraceptives require the consent of the husband because the husband is seen as the head of the family, protector, breadwinner and someone who can make decisions in a family. Adequate knowledge of contraception, can motivate her husband and to encourage the use contraceptives. Contraception cannot be used by the wife without cooperation with her husband and mutual trust. Ideal state that the couple must jointly choose the best contraceptive method, cooperate with each other in use, pay expenses and pay attention to contraception usage danger signs [9] .

In this research the respondents who do not get support from family use contraceptives because the husband wanted the number of children a lot so that children can assist parents in making money and also still a lack of understanding that many children a lot of sustenance. Women who are not permitted by their partners to have family planning tend to use traditional methods more often. Women with these circumstances were also generally prefer an injectable and rarely use barrier methods than women who get the approval of husband [10].

Family support refers to the perceived social support from family members. Family support (husband / wife) considers 


\section{Comparative Study of the Effect of Topical Corticosteroid with Non-Steroidal Anti Inflammatory Agents on Post-Operative Inflammation and Corneal Astigmatism After Cataract Surgery

that people who are supportive are always ready to provide help and assistance if needed [11], Both the nuclear family and the extended family serves as a member of a support system for its members. This is in line with research [12] shows that there is a significant relationship between wives support the participation of men in family planning. Wife's response to vasectomies will be performed by the husband of an endorsement by a wife against her husband. Wife's response can be positive or negative depending on the knowledge, beliefs, attitudes and actions of a role model. This is in line with research conducted by Manurung that support a wife has a relationship in choosing vasectomy / MOP as male contraception [13], This study is also consistent with research Lubis that support the wife had a significant impact on the level of the decision to use tubektomi [7] .

This study is not consistent with the results of research conducted Afsari stating that family support in the choice of contraception is not related to a lack of information that belongs to the family of reproductive health, especially on contraception most wives forbid the husband to use contraceptives because they thought that contraceptives reduce sexual pleasure [14]

Education Relationships With Non-Hormonal Contraceptive Use

Education is one of the factors that can influence knowledge and attitudes about contraception methods. Highly educated people respond more rational and can adapt to the changes to the social than they are educated. They are also more able to adapt to the social changes directly and indirectly in terms of Family Planning [15] .

In this study showed an association between education and the use of non-hormonal contraception. The higher level of education will obviously affect one's personal in the opinion, think, act, be more independent and rational decisionmaking and action. It will also directly affect a person in terms of his knowledge of the orientation of life are included in family planning [16] .

Based on the results of research conducted that highly educated people will respond more rational than those less educated, more creative and more open to their renewal efforts are also more able to adapt to the social changes. Directly or indirectly, in terms of planning. Due to the general knowledge of family planning is taught in formal education in schools in the subjects of health, education, family welfare and population. The higher the education level of the couple who took birth control, the greater the couples who see their children as an important reason to do family planning, so that the higher education increasing proportion of those who know and use contraceptives to limit the number of children.

From the results of this study also found that respondents with less education as many as 56 people (80.0\%). In line with the research Erliani that respondents were willing or unwilling to take advantage of the operating method men are not affected by the high and low levels of formal education of the respondents [17] .

Education is one of the factors that can influence knowledge and attitudes about contraception methods [11] . This is in line with research Anita stated level of education and contraception election interrelated [18]. Education with the mindset, perception and behavior are very significant in the sense that the higher the level of education a person more rational in making decisions. This is also supported by research Indah on research mentioned that there is a relationship between level of education and contraception election [19] . The same study also conducted by the image there is a relationship between level of education and the selection of the use of contraceptives in family planning acceptors in 03 citizens association, Village of Kedung Cowek Surabaya [20] . EFA Women who have a higher education will pick LTM contraceptives because they have a good knowledge about the benefits and risks of contraceptives so they choose a contraceptive that is safe, practical and long-term. The same study by Bhandari stated that the use of female contraceptives and well-educated husband for $65.6 \%$ relates to the use of contraception in Nepal, level of education are more likely to use modern contraceptives than those not having education [21] .

Economic Status Relationship With NonHormonal Contraceptive Use

Revenues have an influence indirectly to the election of contraception. Families with high incomes will be able to meet the needs of contraception use. Conversely low-income families will have trouble meeting the contraceptive use [22]

Based on the study showed an association between economic status withnon-hormonal contraceptive use in Pantoloan Health Center. One of the risk factors that affect the contraceptive is income. Women with a higher household income have a higher chance to use or choose contraception compared to women with low incomes. Based on research conducted Mariza, low family income insufficiency causes need to choose contraception, and also lower socioeconomic causes the mother is not able to access contraceptives so most likely the mother can not use contraceptives.

Family income was significantly related to the use of contraception vasectomy. Revenues proved highly influential on the physical and psychological health conditions acceptors. Acceptors with high incomes will automatically get to the physical and psychological well too, otherwise it will not be burdened acceptor psychologically regarding usage fees and meeting the needs of contraception. Lack of family income led to the inability to achieve a high level so that knowledge is reduced, the lack It increases the risk for not using contraception at family planning acceptors and downs exacerbate population growth.

Knowledge Relations with Non-Hormonal Contraceptive Use

Knowledge is the result of the idea, and this occurred after people perform sensing to a particular object. This sensing occurs through the five senses, the senses of sight, hearing, smell, taste and touch [11] . Most human knowledge is obtained through the eyes and ears. Or cognitive domain knowledge is very important for the formation of a person's behavior [23]

Knowledge is someone who has knowledge of a good contraceptive that the benefits, side effects, how to work or kind 
will be organized and obedient on rules regarding their use. And vice versa people who do not know anything about a contraceptive, then told to use, it is no more likely that will happen is in use and not according to the rules.

Based on the research results there is a relationship between knowledge and the use of non-hormonal contraception. Basically, one's knowledge is different because it has its own level of understanding of an object.This is because couples of childbearing age who do not take advantage of his knowledge and the lack of contraceptive services can be caused by ignorance of couples of reproductive age (EFA) in the use of contraceptives. For mothers who are less active in participating in outreach activities in the local area is expected to consult the midwife on contraceptive suitable for use for herself. Health workers to be more frequent counseling on contraceptives to family planning participants [24] . Someone new to behave in case awarenees that is realized in the sense of knowing and behavior based on the knowledge will be more lasting than that is not based on knowledge [11] . Thus, knowledge of contraception may affect acceptor in choosing a contraceptive. The level of public knowledge will affect the acceptance of family planning programs in the community. Once a woman knows where contraceptive services, distance and time difference is not important in contraceptive use, and has a significant relationship between knowledge about the place of service and a contraceptive method.

This study is in line with research conducted by Grestasari which states there is a relationship between the level of knowledge of mothers with the choice of contraception in the village Jetak Sidoharjo District of Sragen [25]

. The higher the level of education the better in absorbing information so that the level of one's knowledge is also getting better [11]. This shows that the better a person's knowledge is, the better it is to choose contraception that is used while the mother whose knowledge is not good and does not use contraceptive services can be caused due to ignorance of the mother in using contraception.

Respondents who have a high level of knowledge about contraception will be more stable in choosing a contraceptive, while respondents who have a level of knowledge about contraception are low tend to hesitate in choosing the contraception tool. This is in accordance with the theory put forward by Notoatmodjo, which states that exposure to information (mass media) can affect the knowledge within oneself of information obtained from both formal and nonformal education can provide short-term impact (immediate impact) resulting in changes or increased knowledge [11] .

According to the research that the use of contraception in Pantoloan Health Center more who have less knowledge of good and most were using hormonal contraception because the respondents in the Pantoloan Health Center area were less educated and only completed primary school.

\section{CONCLUSIONS:}

The study concluded that there is a relationship between family support, education, economic status and knowledge with non-hormonal contraceptive use in Pantoloan Health Center, Tawaeli District, Palu City. Health workers are expected to provide counseling or information about any method of contraception to acceptors in full so as to improve the continuity of the use of non-hormonal contraceptive methods through good counseling process continuously from the time acceptor determine the choice of contraception and for taking the contraceptive acceptors.

\section{Acknowledgement:}

The authors grateful to all of those whom have had pleasure participated and supported this research

\section{REFERENCES}

[1] LN Mahmudah, "Analysis of Factors Associated with LongTerm Contraceptive Method Selection (LTM) at KB acceptors Banyubiru Women in the District of Semarang District,". Unnes J Public Heal. 2015;2(2):76-85.

[2] World Health Organization, "Long-term Contraceptive Protection, discontinuations and Switching Behavior."; 2014.

[3] [3] suherman, Family Planning Services. Yogyakarta: Rohima Press; 2008.

[4] FA Gosal, "Factors Affecting Contraceptive Method Selection in women of fertile age (WUS) In the village Salassae Bulukumba District of South Sulawesi province,". J Healthy Tadulako; $7(4): 381-388$.

[5] Palu City Health Department, "Mother and Child Health Report,". Hammer; 2016.

[6] AM Marcus, BM Abeeb, and AC Babatunde, "Awareness of Married Men on vasectomy and Its Adoption in Typical Nigerian Indigenous Communities,". Matern Child Health J. 2016;4(5):631-638.

[7] AYM Lubis, "Vasectomy Acceptors Characteristics Influence and Compensation Levels Against Decision to Use Vasectomy in Tebing Tinggi in 2009,"; 2010.

[8] Liando F, Runkat M, Manueke I. Factors Associated With the Use of Contraceptives In Rahim (IUD) In Pangolombian village of Tomohon in 2013,. J Ilm Midwife. 2013 12; Vol.

[9] Hartanto H. No Title. Jakarta: PT. New: Theme; 2010.

[10] Curtis MAMS. Trends and Determinants of Contraceptive Method Choice in Kenya,; 2004.

[11] Notoatmodjo S. Health Promotion and Behavioral Health. Jakarta: Rineka Cipta; 2012.

[12] Indrayani K. Fatma and BW Lestar, "Factors Influencing Selection of Contraception Vasectomy,";

[13] SS Manurung, "Analysis of Factors Affecting husband in Choosing a Vasectomy Contraception in the district. University; 2012.

[14] Afsari, "Adolescent Contraceptive Use Married Women in Indonesia. Center for Research and Development Efforts in Public Health, "Penelit. Kesehat. 2017;45(4):257-266.

[15] Febriyani IS. "Relationship to Education and Knowledge Age Couple Fertile (EFA) Selection Against Contraception Steady in the village of Karangampel Kidul Indramayu district, "2014;

[16] Rizali MI, Ikhsan M, Salmah A. Factors Associated with Injectable Contraceptive Method Selection in the Village Mattoangin Mariso District of the city of Makassar,. J Media Kesehat Mobi Indonesia. 2013;9(3).

[17] Erliani D. Determinants Utilization Operating Method Man (MOP) In the district of Medan Selayang 2014,;

[18] L A, Kusmiati, Dompas R. "Factors Associated With Contraception Selection Eligible Couple. Manado; 2014. 
Comparative Study of the Effect of Topical Corticosteroid with Non-Steroidal Anti Inflammatory Agents on Post-Operative Inflammation and Corneal Astigmatism After

[19] Lovely R. Conduct Of Medical Students In Smoke Hazard To The Images Of Cigarette Packaging (Case Study Medical Faculty And Faculty Of Medicine Abdurrab In Pekanbaru),. Jom Fisip. 2015;2(2):1-12.

[20] Citra M, Astrida B, Adibah E. "The relationship between education level and Number of Children to Selection Use Contraceptives At KB Acceptors," STIKES Hangtuah; 2017.

[21] Bhandari GKS, Thakuri P. Study of factors affecting contraceptive use among married women of reproductive Age,. J Coll Med Sci. 2013;9(4):24-29.

[22] Akwa DS, Obinchemti TE, Tchente CN, Nsom JB, Mangala FN, Mbu R. Knowledge, Attitudes and Practice of Contraception among Refugees in a Refugee Settlement in Yaoundé, Cameroun,. Int J Trop Dis Heal. 2016;13(1):1-10.

[23] AA Rizkitama, "The Relationship of Knowledge, Perceptions, Social and Cultural With Men Active Role In Vasectomy Paguyangan In District Brebes Year 2011-2012,"; 2015

[24] Huda AN, L W, Widjanarko B. Factors Associated with Behavior Use of Contraceptives in Women of fertile age in Jombang Health Center -South Tangerang City,. J Kesehat Mobi. 2016;4(1).

[25] LE Gretasari, "Relationship Between Level of Education, Science, And Age Mother Pus With Selection of Contraception In the village Jetak type Sidoharjo District of Sragen,"; 2014 . 